\title{
13 \\ The Batanes Islands and the Prehistory of Island Southeast Asia
}

\author{
Peter Bellwood and Eusebio Dizon
}

The Batanes research has covered 4000 years of prehistory, with evidence gleaned from many archaeological sites located on four different islands. The chronological sequence of changes in artefacts and their stylistic attributes, especially in pottery, Taiwan nephrite and other lithic artefacts (Fig. 14.1), will form a keystone in the broader understanding of northern Philippine prehistory and relations with adjacent regions. Archaeological data can often be frustrating in their ambiguity, scarcity and level of preservation, but within the whole corpus of data from Batanes there are many observations that can be made with a high degree of confidence.

Some of these observations are based on negative data. For instance, absolutely no archaeological evidence was found to indicate that the Batanes Islands were discovered or settled prior to the Neolithic. Admittedly, lack of recovered evidence need not always reflect a total absence, but in the case of the Batanes it is hard to avoid the assumption, from the red-slipped and cordmarked pottery in Torongan and Reranum Caves, that the first humans to settle these islands permanently came from Neolithic Taiwan in the centuries around 2000 BC. By soon after 1500 BC, at Sunget, Savidug and Anaro, the evidence of Taiwan nephrite and slate, domestic pigs and dogs, red-slipped and stamped pottery, pottery spindle whorls, side-notched stone net sinkers, and grooved and stepped stone adzes reinforces the existence of very strong links with Taiwan. All of these items have a much greater likelihood of origin in Taiwan and southern China than they do from the Wallacean region that lies directly to the south of Batanes, in the main Philippines and central/eastern Indonesia.

Nevertheless, there might be a very significant difference here between early ephemeral visits by hunter-gatherers from Taiwan or Luzon, and actual settlement of the Batanes by a population that remained permanently in place and grew in numbers thereafter. The archaeological record might be showing us the latter, in the form of the Batanes Neolithic, and masking any faint traces of the former. The Batanes Islands are very small and depauperate in native resources, being neither part of Sundaland nor indeed ever linked by dry land to any other region. This makes it possible that any hunter-gatherer settlements in Batanes during the Pleistocene or early Holocene might not have survived for long, just as many of the more remote offshore islands adjacent to Australia (Kangaroo Island, Bass Strait Islands) were abandoned as they became cut off by postglacial sea level rise. Similar points have been made about small islands in eastern Indonesia, for instance by 
Ono et al. (2008), although it must be remembered that these small Indonesian islands at least have an archaeological record of a fleeting Palaeolithic presence in caves. The Batanes Islands do not, despite also having quite numerous caves.

Nevertheless, two other observations render a slim possibility of occasional pre-Neolithic nonsedentary settlement in Batanes at least worthy of consideration. Firstly, using parallels from the many remote Oceanic islands settled by Austronesian-speaking populations, particularly in Polynesia, we might expect that the Batanes Islands hosted many species of bird and reptile at the time of first human arrival, and that these would have been rapidly extirpated by human hunters (Steadman 2006). Alas, however, the bone records from Torongan and Reranum were too poor to reveal clear evidence on this issue, so the issue remains open. Likewise, reflecting on the relative scarcity of shell midden in Batanes, the authors of chapter 12 ask if sites such as Torongan and Anaro record the initial settlement of the Batanes, or whether there might be earlier sites which contain the sort of shell midden that would be expected from the targeting of unexploited shellfish populations. So far, there are no such sites. Is this because the records are too poor, or is it possible that pre-Neolithic hunters had already extirpated many resources before Neolithic settlers arrived? At present, we do not know.

Two other rather more disappointing negatives from the Batanes research also merit comment here, before focusing on the more positive results of the research. Firstly, we were not lucky in finding human remains, except for a single skeleton of very late prehistoric date with no grave goods from Dios Dipun shelter on Batan, and some small fragments of human bone from the Savidug jar burials. We know nothing about the biological affinities, health, or stable isotope dietary signatures of the first Batanes islanders. Added to this, we have virtually no archaeobotanical record for Batanes. Reasons for this are discussed in an appendix to this chapter.

Moving now towards positive evidence, derived from what we did rather than did not find, we have a strong sequence of artefact variation covering the past 4000 years in Batanes, both in basic presence-absence terms and in details of stylistic attributes. Some sites have also produced good records of animal exploitation, both marine and terrestrial, as discussed in chapters 10 to 12 . One general conclusion is evident, and this is that the Batanes Islands were not just settled once from Taiwan and thereafter isolated until Jirobei and Dampier arrived in the late seventeenth century. There are indications that arrivals from Taiwan, and probably movements in the other direction as well, happened on many occasions.

For instance, it is unlikely that all the Taiwan nephrite and slate artefacts found in Batanes were brought in by just one founder canoe. It must be remembered that Taiwan nephrite was taken to many regions of Southeast Asia in the period from 500 BC to AD 500 (Hung et al. 2007; Hung and Bellwood 2010), rendering it obvious that contacts with Taiwan at this time happened much more than once. They also happened long before this time, given the evidence from Sunget (c.1000 BC), and the two Taiwan nephrite bracelet fragments found at the base of Nagsabaran in the Cagayan Valley (c.2000-1500 BC; see chapter 9). The Batanes Islands must also have received frequent contacts from Luzon moving in the other direction, given the extent of island intervisibility (chapter 2). In the same direction, a Batanic language (Yami) was carried in late prehistory from Itbayat to Lanyu Island, just southeast of Taiwan. Exactly when this occurred is not clear, but it is generally assumed that the ancestral Yami language arrived from Batanes in Lanyu after initial settlement of that island from Taiwan, the latter presumably during the earlier phases of the Neolithic.

In terms of general Taiwan-Batanes contact via the mediation of Lanyu Island, the dramatic discoveries made between 1978 and 1982 at the site of Rusarsol on Lanyu (Hsu 2008) are of very great relevance. This site has yielded Anaro circle-stamped type 1 pottery, pelta-shaped nephrite debitage identical to the pieces from Anaro shown in Fig. 9.7, slate knives, a biconical spindle 
whorl, possible clay earrings, and other sherds of red-slipped pottery and pottery appendages similar to Batanes examples. At Anaro, such materials date to the later part of cultural phase 2 in the Batanes sequence, $c .500 \mathrm{BC}$ to $\mathrm{AD} 1$, as discussed in chapters 5 and 6 . There is also a corrugated rim from Rusarsol with stamped half-circle decoration almost identical to one from Mitangeb on Siayan Island (Fig. 6.10, top). The Rusarsol assemblage is not in itself directly dated, and appears to be mixed with much younger imported Chinese ceramics, suggesting that the site might have several chronological components. It is also not known if any of the Rusarsol pottery artefacts actually came from Batanes, or were produced in Lanyu. But whatever the answer, it is clear that Itbayat and Lanyu were in very definite contact between at least $500 \mathrm{BC}$ and the early centuries AD.

Another conclusion must be that Batanes prehistory, at least as known through the past 4000 years, shows no sign of any hiatus in occupation or dramatic cultural replacement, except for the possibility of a period of fairly localised abandonment of central Batan following the Iraya eruption around $\mathrm{AD} 500$. This raises the probability that the initial Neolithic inhabitants of Batanes were the relatively direct ancestors of the people who lived there at the end of prehistory, and likewise of the modern Ivatans and Itbayaten (Ross 2005). This ancestry may extend to the modern Yami of Lanyu as well, given that Yami is a Batanic and not a Formosan language.

It is interesting that the Batanic languages as a whole (Ivatan, Itbayaten and Yami) have a very low internal diversity, despite the fact that they subgroup uniquely with no other Philippine languages. This presumably reflects the ease and frequency of interisland communication for people with a competent technology of boat construction. The Batanic languages are therefore deeply rooted within the major Malayo-Polynesian subgroup of the Austronesian language family, even if they remain internally rather undifferentiated. This suggests that the Batanes Islands populations have behaved linguistically as inhabitants of a single interlinked archipelago throughout their prehistory, rather than as residents of completely separate islands whose populations never came into contact.

Exactly how much contact occurred between Batanes and Lanyu is not so clear, and a recent $Y$ chromosome and mitochondrial genetic survey has found rather few traces of gene flow between Ivatans and Yami (Loo et al. 2011). However, the very clear archaeological evidence of contact between Itbayat and Lanyu around 2000 years ago, discussed above, cannot be ignored. In this case the contact obviously involved some population movement since it was across sea, by boat.

Turning now to some specific aspects of the Batanes archaeological record, the artefact and economic sequences recovered have been described fully in chapters 6 to 12, and some of the main observations are shown in Fig. 13.1, also printed earlier as Fig. 5.3. The four major phases recognised within Batanes prehistory are based on visible changes in artefact decoration and style, and are not intended to be rigid and non-overlapping. Phase 1, with its red-slipped plain pottery from Torongan and Reranum, and limited amounts of cord-marked pottery from Reranum, is still rather fugitive and known only from caves. Phase 2 (outer limits $1300 \mathrm{BC}$ to AD 1) is perhaps the most prominent in all of Batanes prehistory, being represented by large assemblages from the major open sites of Sunget, Anaro, and Savidug Dune. The range of artefacts with Taiwan parallels in Phase 2 is quite remarkable, as mentioned so many times during the course of this monograph. After $500 \mathrm{BC}$, this was also the phase of major importation of Taiwan nephrite and slate into Batanes and Lanyu, the former worked from blanks at Anaro and Rusarsol into circular ear ornaments similar to the lingling-o ornaments of early Metal Age date found across so many regions of Southeast Asia. Indeed, as discussed in chapter 6, the pottery sequence from Anaro allows us to divide Phase 2 into two subphases, as defined by variations in the stylistic composition of stamped circle motifs on pottery.

However, the strong Phase 2 emphasis on pottery decoration using motifs created purely from rows of stamped circles was always rather unique to Batanes, with direct parallels existing only in 
Taiwan and in offshore Taiwanese sites such as Youzihu on Ludao Island and Rusarsol on Lanyu Island. This rather obsessive focus on stamped circles was a little different from the varieties of circle stamping combined with zones of punctate or dentate stamping that characterised sites in the Cagayan Valley of Luzon (e.g. Magapit, Nagsabaran, Irigayen) and elsewhere in the Philippines (e.g. Batungan Caves on Masbate Island), in the early culture of the Mariana Islands (House of Taga and Achugao), and in Lapita sites in Oceania (Carson et al. 2013). This might relate to a relative self-containment of the Batanes stylistic scene, suggesting that these islands in themselves were not sources of major colonising voyages to the south or east.

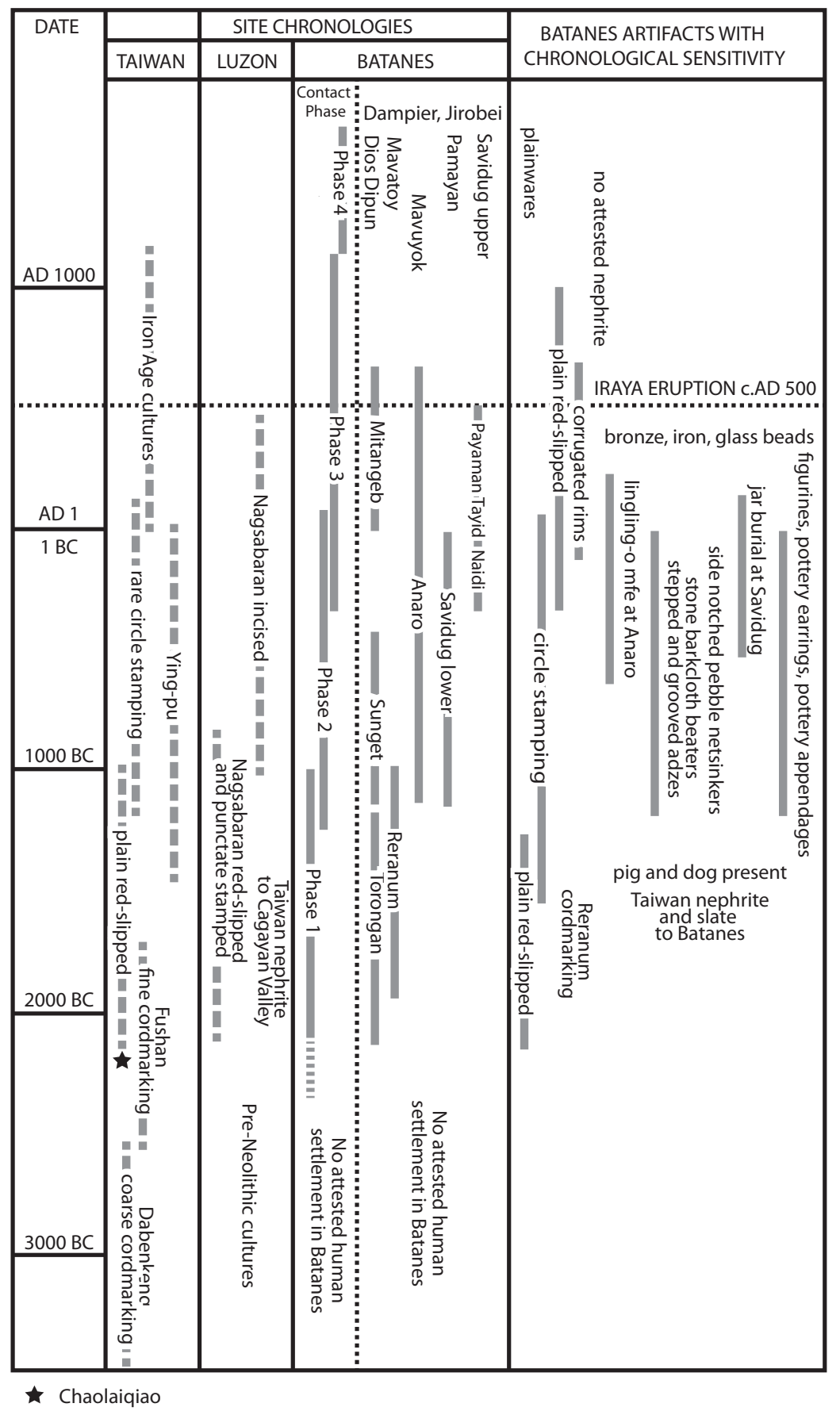

Figure 13.1. The four proposed phases for Batanes prehistory, together with radiocarbon chronologies for the excavated Batanes sites, and contemporary cultural manifestations in Taiwan and Luzon.

Source: Peter Bellwood. 
This final point, of course, brings up the role of the Batanes Islands in the whole saga of Austronesian origins and migrations across Island Southeast Asia, into Oceania, and even to Vietnam and Madagascar. This monograph is not the place to repeat the many observations made over many years on this issue by the senior editor, who has published recent summaries elsewhere of the out-of-Taiwan hypothesis for Austronesian origins, involving human migration rather than language shift or "cultural diffusion" alone (Bellwood 2011a, 2011b; Bellwood et al. 2011). This Terra Australis monograph on Batanes archaeology has been published as a source of data, rather than as an argument for or against a specific historical position in the field of Austronesian origins. Its purpose is to allow readers to examine and assess some very significant data for themselves, relating to human movements between Taiwan and the northern Phipippines during the past 4000 years, in order to have an opinion, should they wish one, on this muchdebated issue. 